\title{
多数の浮体で支持された長大な半潜水式 構造体の波浪応答解析
}

\author{
正員 吉 田 宏一郎* 正員 具 滋 三** \\ 正員 岡 徳 昭*
}

Response Analysis of Huge Semisubmersible Type Structures Supported by a Large Number of Floating Bodies in Waves

\author{
by Koichiro Yoshida, Member Ja-Sam Goo, Member \\ Noriaki Oka, Member
}

\begin{abstract}
Summary
A numerical procedure is described for predicting the motions and the structural responses of huge offshore structures supported by a large number of three-dimensional floating bodies of arbitrary shape in waves. The developed numerical approach which is accurate in linear system is based on combination of a three-dimensional source distribution method, wave interaction theory and the finite element method of using the space frame element. Numerical results are compared with the experimental ones of the structural responses of a freely floating semisubmersible type structure supported by 8 lowerhulls and 16 columns in shallow water. The results of comparison confirmed the validity of the proposed approach. The method presented is applicable to huge structures for ocean space utilization which seem to be brought into practical use in the future.
\end{abstract}

\section{1. 緒言}

著者らは前報”において, 三次元特異点分布法と Kagemoto らの相互干涉理論 ${ }^{2) .31}$ を基礎として, 多数の三次 元任意形状浮体間の流体力学的相互干涉効果を考慮して波 強制力, 運動応答を効率よく解析する方法を開発した。こ れまでに発表された代表的な相互干渉効果に関する計算值 及び実験值と比較することにより，この解析法の精度を確 認すると共に, 4 行 10 列の 40 個の箱型浮体群について波 強制力, 運動応答を解析した。

一方, 著者らは以前に, 半潜水式構造や緊張係留プラッ トフォームの上部構造を三次元弾性骨組と仮定して波浪応

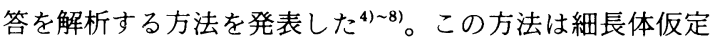
に基づく流体力の近似評価, 構成部材間の流体力学的相互 干渉の無視, マトリックス構造応答解析法に基づくモデル 化などから成立している。

本研究では, 上述した波浪応答に関する流体力評価の精 密化と上部構造の弾性骨組仮定とを組み合わせ，構造体に

* 東京大学工学部

** 東京大学大学院工学系研究科
よる海洋空間利用の推進のために必要となる, 多数の大型 浮力体とこれらにより支持された大規模上部構造とから構 成される半潜水式構造体の波浪応答を精度よく解析する方 法を開発した。 8 箇のコラムーロワーハル型支持浮体とリ ング状甲板梁からなる半潜水式リング状構造体の波浪強制 実験を実施し, 主要構造応答である甲板梁の垂直曲げ歪の 周波数応答関数について良好な相関が確認され，本方法の 有効性が明らかとなった。

\section{2. 理論計算法}

本論文では三次元任意形状浮体間の相互干涉については 簡単に触れるので, 詳細については先に発表した著者らの 論文 ${ }^{1)}$ を参考にされたい。まず，理論の仮定として，上部構 造は三次元線形弾性骨組構造とする。流体は非圧縮性, 非 粘性とし，流体の運動は非回転であるとする。また，弾性 応答と入射波の流体運動は微小振幅周期運動をするものと し，それぞれの定常状態を論ずることにする。また，自由 表面はすべての方向に無限に広がっているものとし, 水深 が有限の場合は水深一定とする。

Fig. 1 のように平均水面上の空間固定された局所デカル 卜座標系 $o_{i}-x_{i} y_{i} z(i=1 \sim N)$ を持つ $N$ 個の三次元任意 


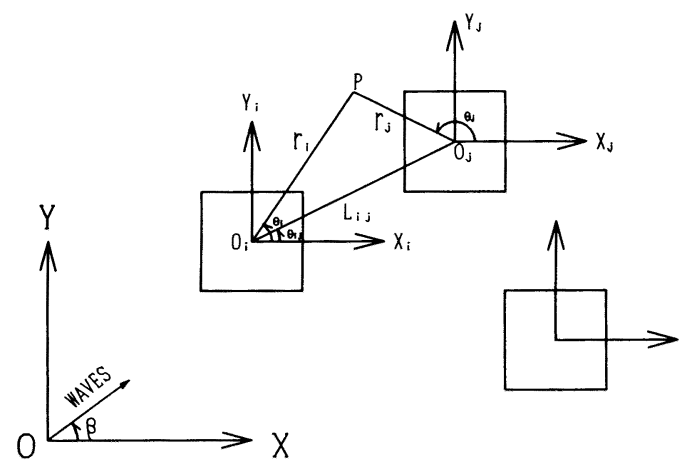

Fig. 1 Definition sketch

形状支持浮体を有する構造体の定常状態の流力弾性問題を 考える。そして局所座標系の原点 $o_{i}(i=1 \sim N)$ は支持浮 体 $i(i=1 \sim N)$ に外接する仮想の鉛直円柱の中心とし, $z$ 軸は鉛直上方を正とする。 $N$ 個の支持浮体が微小振幅周 期運動をしている場合の支持浮体 $j$ の全入射 potential $\phi_{j}{ }^{I}$ は次のように書ける。

$$
\begin{aligned}
\phi_{j}{ }^{I}\left(r_{j}, \theta_{j}, z\right)= & \left(\left\{a_{j}\right\}^{T}+\sum_{\substack{i=1 \\
i \neq j}}^{N}\left\{A_{i}\right\}^{T}\left[T_{i j}\right]\right)\left\{\phi_{j}^{I}\right\} \\
& +\sum_{\substack{i=1 \\
i \neq j}}^{N} \sum_{l=1}^{6}\left(-i \omega \eta_{t i}\left\{R_{l i}\right\}^{T}\left[T_{i j}\right]\right)\left\{\phi_{j}{ }^{I}\right\}, \\
& (j=1 \sim N)
\end{aligned}
$$

ここで, $\left(r_{j}, \theta_{j}, z\right)$ は支持浮体 $j$ の局所円柱座標である。 また, $\left\{a_{j}\right\}^{T}$ は支持浮体 $j$ の局所円柱座標で表わされた進行 波の potential の係数 vector の転置であり, $\left\{A_{i}\right\}^{T}$ は次式 で表される支持浮体 $i$ に外接する仮想の水底にまで達して いる鉛直円柱の外側の diffraction potential $\phi_{i}^{\prime D}$ の係数 vector の転置である。

$$
\phi_{i}^{\prime D}\left(r_{i}, \theta_{i}, z\right)=\left\{A_{i}\right\}^{T}\left\{\psi_{i}^{\prime D}\right\}
$$

ここで, $\left\{\psi_{i}^{\prime D}\right\}$ は支持浮体 $i$ の近傍の振動する成分波の流 れ場を表現する第 1 種 $n$ 次 Hankel 関数 $H_{n}^{(1)}$ 及び単調減 少する成分波の流れ場を表現する第 2 種 $n$ 次変形 Bessel 関数 $K_{n}$ で表される散乱成分波を要素とする vector であ る。

また, 式 (1)の $\left\{\phi_{j}{ }^{I}\right\}$ は支持浮体 $j$ の第 1 種 $n$ 次 Bessel 関数 $J_{n}$ 及び第 1 種 $n$ 次変形 Bessel 関数 $I_{n}$ で表わされる 入射成分波を要素とする vector である。また, $\left[T_{i j}\right]$ は支持 浮体 $i$ の散乱成分波を支持浮体 $j$ の入射成分波に変換する 座標変換行列である。また, $i$ は虚数単位であり, $\omega$ は波の 円周波数であり, $\eta_{l i}$ は支持浮体 $i$ の取付節点での $l$ 方向の 複素変位振幅である。また, 支持浮体 $i$ が単独に存在し, $l$ 方向に単位速度振幅で運動しているときの支持浮体 $i$ に外 接する仮想の水底にまで達している鉛直円柱の外側の radiation potential $\phi_{l i}^{\prime R}$ は次のように表わされているもの とする。 $\phi_{l i}^{\prime R}=\left\{R_{l i}\right\}^{T}\left\{\phi_{i}^{\prime D}\right\}=\left\{R_{l i}\right\}^{T}\left[T_{i j}\right]\left\{\psi_{j}^{\eta}\right\}$

ここで, 転置 vector $\left\{R_{l i}\right\}^{T}$ の要素は支持浮体 $i$ が単独に 存在している場合の $l$ 方向の運動による radiation 問題を 解いて得られる係数である。

支持浮体 $j$ の全入射 potentialに対する diffraction potential はdiffraction 伝達行列 $\left[B_{j}\right]$ によって次のよう に表わされる。

$$
\begin{aligned}
\phi_{j}^{\prime D}\left(r_{j}, \theta_{j}, z\right) & =\left(\left\{a_{j}\right\}^{T}+\sum_{\substack{i=1 \\
i \neq j}}^{N}\left\{A_{i}\right\}^{T}\left[T_{i j}\right]\right. \\
& \left.+\sum_{\substack{i=1 \\
i \neq j}}^{N} \sum_{l=1}^{6}\left(-i \omega \eta_{l i}\left\{R_{l i}\right\}^{T}\left[T_{i j}\right]\right)\right) \\
& \cdot\left[B_{j}\right]^{T}\left[\psi_{j}^{\prime D}\right\}, \quad(j=1 \sim N)
\end{aligned}
$$

ここで, $\left[B_{j}\right]^{T}$ の $p$ 行の要素は $\left\{\phi_{j}^{n}\right\}$ の $p$ 番目の要素の入 射成分波が単独の支持浮体 $j$ に入射した場合の diffraction 問題を解くことによって得られる支持浮体 $j$ の近傍の散乱成分波の係数からなっている。従って,式 (2) の浮体 $j$ に対する表示式と式(4) から次式が得られる。

$$
\begin{aligned}
\left\{A_{j}\right\}= & {\left[B_{j}\right]\left(\left\{a_{j}\right\}+\sum_{\substack{i=1 \\
i \neq j}}^{N}\left[T_{i j}\right]^{T}\left\{A_{i}\right\}\right.} \\
& \left.+\sum_{\substack{i=1 \\
i \neq j}}^{N} \sum_{l=1}^{6}\left(-i \omega \eta_{l i}\left[T_{i j}\right]^{T}\left\{R_{l i}\right\}\right)\right), \quad(j=1 \sim N)
\end{aligned}
$$

上式を解くのみならず, 上部構造物の内力を求めるため に, $N$ 個の支持浮体の取付節点を含む全体運動方程式が必 要である。D'Alambert の原理に基づいて, 支持浮体 $j(j=$ $1 \sim N)$ の取付節点で評価した複素外力振幅は次式のよう に表される。

$$
\begin{gathered}
\sum_{l=1}^{6}\left[\omega^{2}\left(M_{k l j}+\mu_{k l j}\right)+i \omega \nu_{k l j}-K_{k l j}\right] \eta_{l j}-i \rho \omega \\
\left(\left\{a_{j}\right\}^{T}+\sum_{\substack{i=1 \\
i \neq j}}^{N}\left\{A_{i}\right\}^{T}\left[T_{i j}\right]\right. \\
\left.+\sum_{\substack{i=1 \\
i \neq j}}^{N} \sum_{l=1}^{6}\left(-i \omega \eta_{l i}\left\{R_{l i}\right\}^{T}\left[T_{i j}\right]\right)\right) \cdot \iint_{S_{H j}}\left(\left\{\psi_{j}\right\}\right. \\
\left.+\iint_{S_{H j}}\left\{\sigma_{j}\right\} G_{j} d s\right) n_{k j} d s, \\
(k=1 \sim 6 ; j=1 \sim N)
\end{gathered}
$$

ここで, $M_{k l j}$ は支持浮体 $j$ の取付節点で評価した慣性力 係数, $\mu_{k l j}$ 及び $\nu_{k l j}$ は支持浮体 $j$ が単独に存在する場合の 取付節点で評価した付加質量及び減衰係数であり， $K_{k l j}$ は 支持浮体 $j$ の取付節点で評価した静水圧による復原力係数 である。この復原力係数を求める場合, 支持浮体 $j$ が受け持 つ重量の重心が必要である。また, $\rho$ は水の密度, $n_{k j}$ は支 持浮体 $j$ の $k$ 方向の一般方向余弦, $S_{H j}$ は支持浮体 $j$ の没 水表面であり, vector $\left\{\sigma_{j}\right\}$ の $p$ 番目の要素は $\left\{\psi_{j}^{n}\right\}$ の $p$ 番目 の要素の入射成分波が単独の支持浮体 $j$ に入射した場合の diffraction 問題の積分方程式を解くことによって得られ る支持浮体 $j$ の没水表面上の sourceの面密度であり, $\left[B_{j}\right]^{T}$ の $p$ 行の要素を求める時, すでに得られているもの 
である。また, $G_{j}$ は支持浮体 $j$ の没水表面上の Green 関数 である。

従って, $N$ 個の支持浮体の取付節点を含む系の全体運動 方程式は次のようになる。

$$
\left([K]-\omega^{2}[M]-i \omega[C]\right)\{\eta\}=\{F\}
$$

ここで, $[K]$ は上部構造の剛性行列, $[M]$ は上部構造の 質量行列, $[C]$ は上部構造の減衰行列である。 $\{\eta\}$ は総自由 度の複素変位振幅 vector である。また, $\{F\}$ は複素外力振 幅 vectorであり, その成分は支持浮体の取付節点では式 （6）を用い, 他の節点では 0 である。上部構造の剛性行列 及び質量行列は上部構造を梁要素と近似して求める。上部 構造の減衰行列は Rayleigh 減衰を用いることにする。本 program では汎用性を考えて上部三次元骨組構造のせん 断変形及び回転慣性も含むようにし, 支持浮体の取付節点 以外の節点での境界条件も取り扱うことができる。系の全 体運動方程式である式 ( 7 ) と式 (5) との連立方程式を解く ことによって, 総自由度の複素変位振幅 vector $\{\eta\}$ 及び係 数 vector $\left\{A_{i}\right\}(i=1 \sim N)$ が得られる。従って, 上部構造 の内力は要素剛性行列を用いることによって得られるし, 支持浮体 $j$ の没水表面上の任意点 $\left(x_{j}, y_{j}, z\right)$ の変動圧力の 複素振幅 $P_{j}$ は次式によって得られる。

$$
\begin{aligned}
P_{j} & =i \rho \omega\left[\left(\left\{a_{j}\right\}^{T}+\sum_{\substack{i=1 \\
i \neq j}}^{N}\left\{A_{i}\right\}^{T}\left[T_{i j}\right]\right.\right. \\
& \left.+\sum_{\substack{i=1 \\
i \neq j}}^{N} \sum_{l=1}^{6}\left(-i \omega \eta_{l i}\left\{R_{l i}\right\}^{T}\left[T_{i j}\right]\right)\right)\left(\left\{\psi_{j}\right\}+\iint_{S_{H j}}\left\{\sigma_{j}\right\} G_{j} d s\right) \\
& \left.+\sum_{\substack{l=1 \\
6}}\left(-i \omega \eta_{l j} \phi_{l j}^{R}\right)\right]-\rho g\left\{\eta_{3 j}+\left(y_{j}-y_{m_{j}}\right) \eta_{4 j}\right. \\
& \left.-\left(x_{j}-x_{m j}\right) \eta_{5 j}\right\}
\end{aligned}
$$

ここで, $\mathrm{g}$ は重力加速度, $\phi_{L j}^{R}$ は単独の支持浮体 $j$ が $l$ 方 向の単位速度振幅で運動しているときの支持浮体 $j$ の没水 表面上の radiation potential である。また, $\left(x_{m j}, y_{m j}, z_{m}\right)$ は支持浮体 $j$ の取付節点の座標である。このように, 本動的 応答解析法はある支持浮体に外接する仮想の水底にまで達 している鉛直円柱の内側に他の支持浮体が存在してはなら ないという制限があるものの, 線形の範囲内では厳密な計 算手法である。

\section{3. 実験}

多数の三次元任意形状支持浮体間の流体力学的相互干涉 効果を考慮した運動一構造応答解析法の妥当性の検証のた め, Fig. 2 に示す半潜水式構造体を用いた水槽実験を行っ た。材料は全部アクリルであり, 没水水深を維持するため, 各々の支持浮体に $5.93 \mathrm{Kgf}$ のおもりを二つずつ入れた。 上部構造の断面及び支持浮体の寸法の詳細は Fig. 3 に示 している。また, 浮体の質量は $0.017765 \mathrm{Kgf} \cdot \mathrm{s}^{2} / \mathrm{cm}$, 浮体 のみの重心は水面下 $20 \mathrm{~cm}$, 上部構造を含む場合の浮体の 重心は水面下 $19.1 \mathrm{~cm}$ である。また, 浮体のみの重心回り
の $x, y, z$ 軸に関する慣性モーメントは各々 $2.76,6.57$, $4.49 \mathrm{Kgf} \cdot \mathrm{s}^{2} \cdot \mathrm{cm}$ である。但し, これらの基準座標系につい ては後に述べる。また, 半潜水式構造体の heave 及び pitch の計測された固有周期は各々 $1.89 \mathrm{sec}(3.32 \mathrm{rad} / \mathrm{sec}), 1.97$ $\sec (3.19 \mathrm{rad} / \mathrm{sec})$ である。水槽実験は, 水深 $304 \mathrm{~cm}$, 波 入射角 $180^{\circ}$, 周期 $0.55 \sim 2.6 \mathrm{sec}$, 波高 $2.0 \sim 4.5 \mathrm{~cm}$ の範囲 の規則波によって行われた。波高は容量式波高計で計測さ れた。また,Fig. 2 の上部構造にある黒丸は歪ゲージが貼付 されている部分を示し，これにより支持浮体間の中間部分 の軸歪, 曲げ歪の変動を計測した。また, 波上側の支持浮 体について変動圧力を計測した。Fig. 3 のロワーハルにあ る黒丸は圧力計が取付されている一つの部分を示している が, 変動圧力はロワーハルの両側面, 上下面の中央部分で 計測した。圧力計は共和電業株式会社の PGM-G 型圧力変 換器を用いた。変動圧力の計測結果については後の機会に 譲りたい。

\section{4. 比較及び考察}

半潜水式の構造体の単独の支持浮体の diffraction 問題 及び radiation 問題を解く場合, 三次元特異点分布法を用 い, 支持浮体の没水表面の要素分割数を Fig. 4 のように 344 要素で計算した。また, 式 ( 2 )の diffraction potential は振動項を 9 個, 単調減少項を 14 個で計算した。半潜水式 の構造体の上部構造の計算は有限要素法を用い, その要素 分割を Fig. 5 に示す。黒丸は節点を示し, 実線は梁要素を

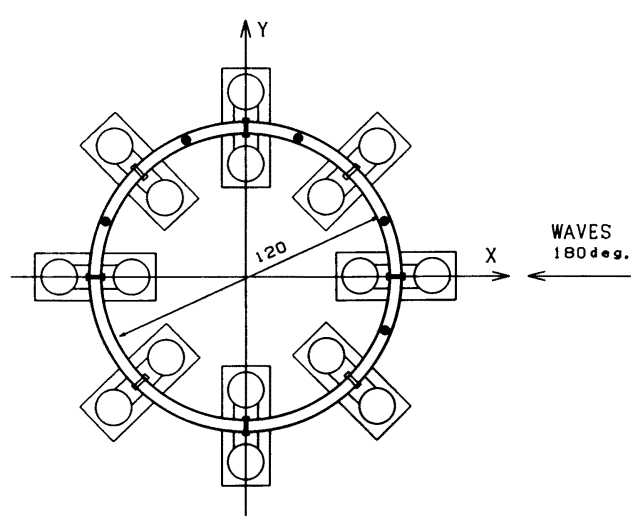

UNIT: Cm

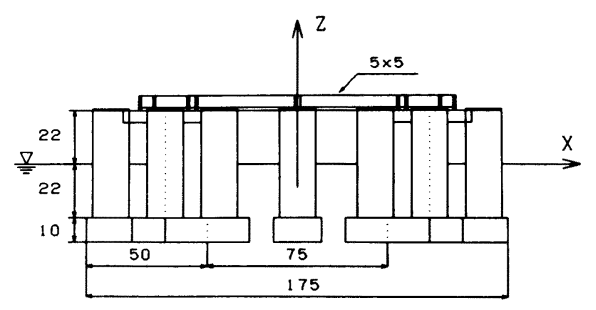

Fig. 2 Configuration of the test model 

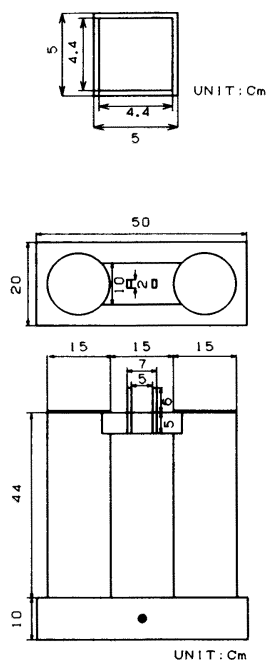

Fig. 3 Configuration of the upper structure and the floating body

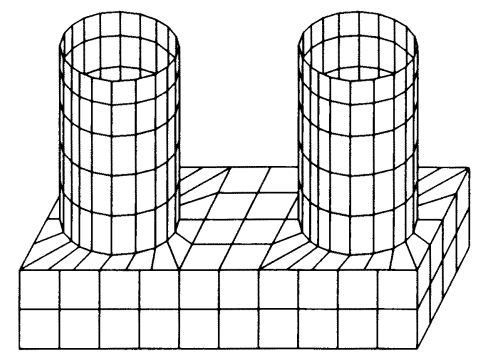

Fig. 4 Submerged surface of the floating body represented by 344 panels

示す。節点番号がある部分が支持浮体の取付節点である。 総節点数 32 , 総要素数 32 , 総自由度数 192 である。また, Fig. 5 における座標系 $X Y Z$ は全体座標系であり, 支持浮 体の位置, 上部構造の節点座標, 支持浮体の取付節点以外 の節点の境界条件, 節点変位, 節点反力はこの座標系を用 いる。また，座標系 $x y z$ は三次元特異点分布法を用いる場 合の基準座標系であり, 支持浮体の没水表面の要素座標, 支持浮体の重心, 支持浮体の慣性モーメント, 支持浮体の 運動基準点（即ち, 支持浮体の取付節点の座標）はこの座 標系を用いる。また, 座標系 $x^{\prime} y^{\prime} z^{\prime}$ は有限要素法を用いる 場合の要素座標系であり, 上部構造の要素の断面二次モー メント, 要素のねじり係数, 要素内力はこの座標系を用い る。計算結果と実験結果との比較例を Fig. 6, Fig. 7 に示 す。いずれの図においても，横軸は入射波の円周波数 $\omega(\mathrm{rad} / \mathrm{sec})$ であり, 黒丸は実験值, 実線は支持浮体間の流 体力学的相互干涉効果を考慮した計算值, 点線は単独の支 持浮体の流体力及び波強制力は三次元特異点分布法を用い るものの, 支持浮体間の相互干涉効果を考慮せず, 波の位 相だけ考慮した計算值である。また，実線及び点線は 53 個

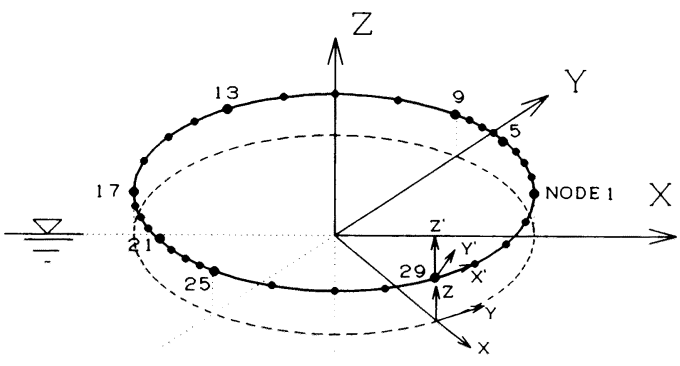

Fig. 5 Coordinate system and discretization of the upper structure

の周波数応答を直線で連結したものである。また，構造の 全体減衰行列は全体剛性行列に比例する Rayleigh 减衰を 用い, その係数は, 複雑な構造体の場合, 実験的にも精度 よく評価することが難しいので,よく用いられる 0.01 を用 いた。Fig. 6 は図中の平面図に黒丸で示した場所における 単位波振幅当りの軸歪振幅の周波数応答である。Fig. 6 の (b)，(c)の 5〜 $7 \mathrm{rad} / \mathrm{sec}$ 近傍を除いてほほよい相関を示 している。尚,この 5〜 7 rad/sec 近傍では Fig. 7 の（b ), (c )からわかるように垂直曲げ歪が非常に大きくなり，そ の影響により值の相対的に小さな軸歪の計測值の誤差が大 きくなったものと考えられる ${ }^{8}$ 。Fig. 7 は単位波振幅当りの 垂直曲げ歪振幅の周波数応答である。この曲げ歪が支配的 であり, 軸歪より一桁大きくて水平曲げ歪より 2 倍程度大 きい。従って，このような半潜水式リング構造体を設計す るときは垂直曲げ応力に注意が必要である。また, 相互干 涉を考慮した計算值と実験值の相関が比較的によいことが わかる。Fig. 7 の（b)，（c）に代表されるように，相互干渉 効果によって peack 值が少し低周波数へ移っていること がわかる。また, 応答が大きい $6 \mathrm{rad} / \mathrm{sec}$ 付近で相互干涉効 果によって曲げ歪が小さくなっていることと後の運動応答 から見ても相互干涉効果はこのような半潜水式構造体に好 ましい影響を与えていることがわかる。また, $3 \mathrm{rad} / \mathrm{sec}$ 付 近での相互干涉を考慮した計算値が少し飛び出しているの は構造体の固有周期の影響であり，この固有周期の近傍で は構造体の運動が大きいので, 粘性による減衰の影響が大 きいと考えられる。位相だけ考慮した計算はこの付近で計 算値が発散する。これは固有周期の近傍での造波減衰を相 互干涉を考慮した場合より小さく評価したことによるもの であると考えられる。Fig. 8 は単位波振幅当りの水平曲げ 歪振幅の周波数応答である。他の場所での応答については 大きさ及び傾向がほとんど同じであり, 軸歪或は垂直曲げ 歪の傾向と違っていた。これは斜めに配置された支持浮体 の yawing モーメントの影響が支配的であろうと考えられ る。Fig. 9 は単位波振幅当りのねじりモーメント振幅の周 波数応答である。他の場所での応答は紙数の都合で示され 


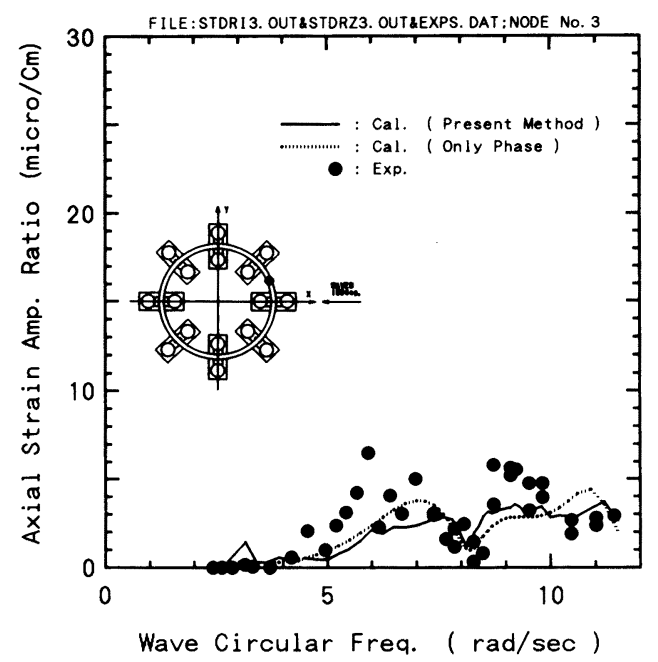

(a)

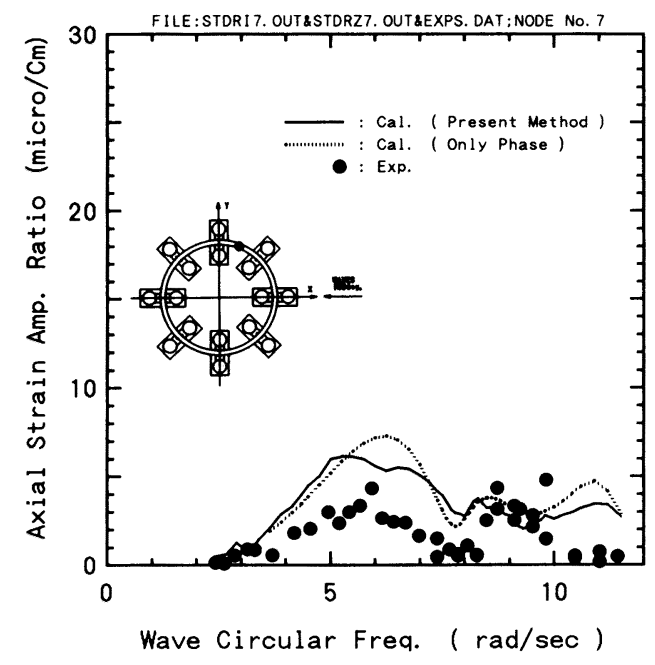

(b)

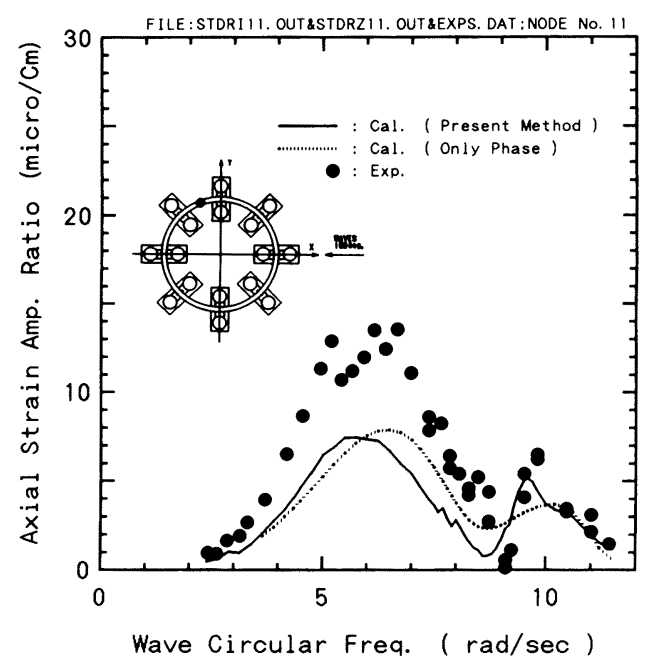

(o)

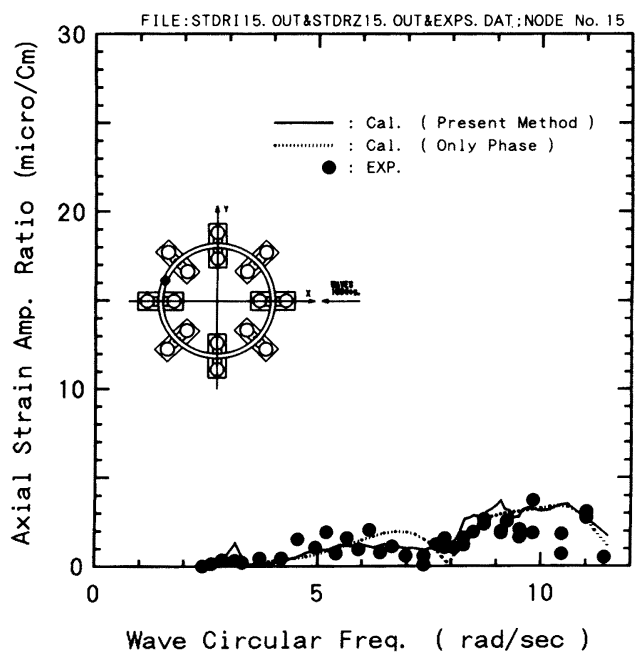

(d)

Fig. 6 Axial strain responses of the upper structure 


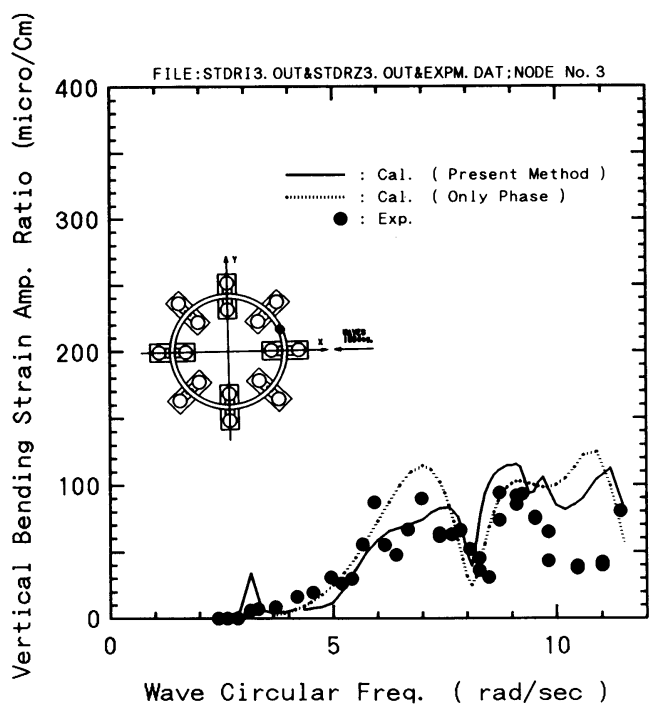

(a)

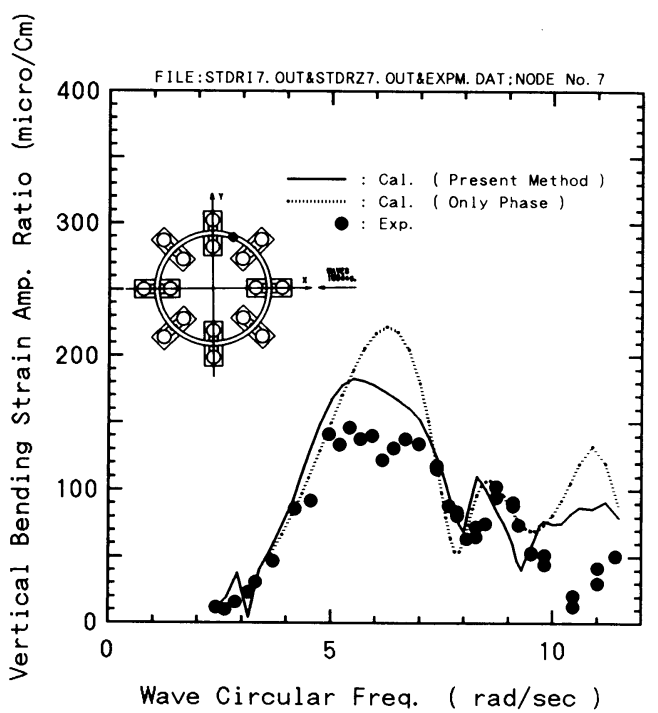

(b)

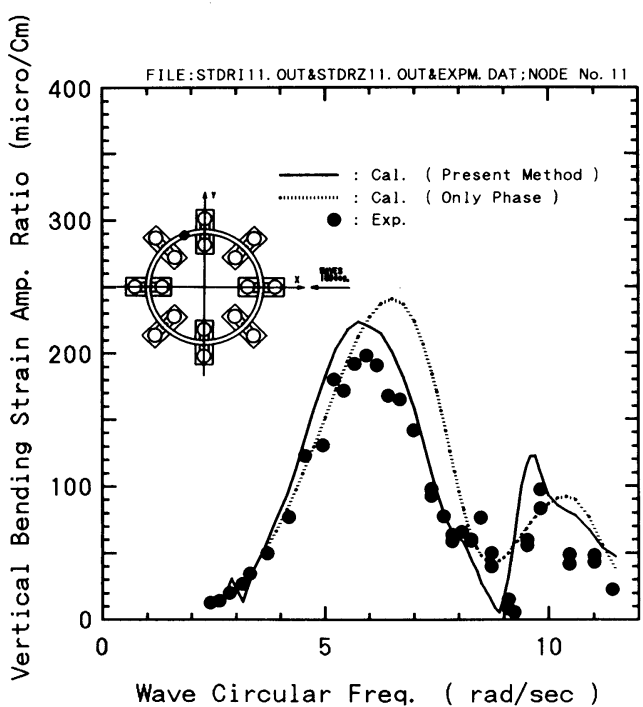

(c)

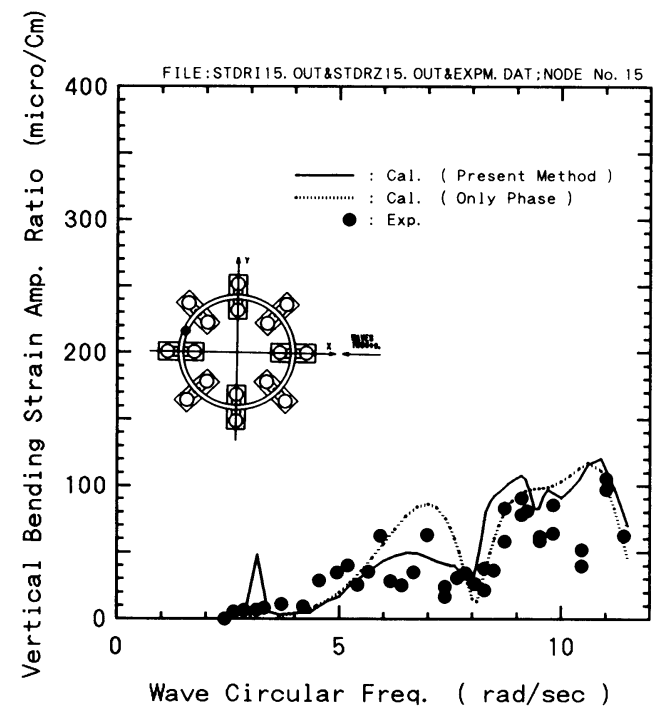

(d)

Fig. 7 Vertical bending strain responses of the upper structure 


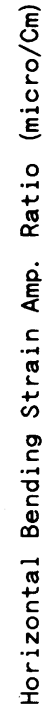

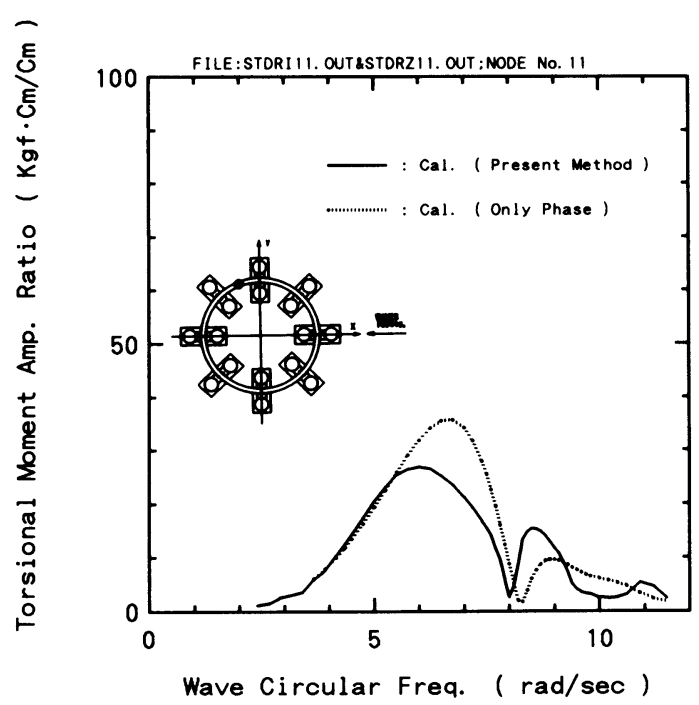

Fig. 8 Horizontal bending strain responses of the upper structure

Fig. 9 Torsional moment responses of the upper structure

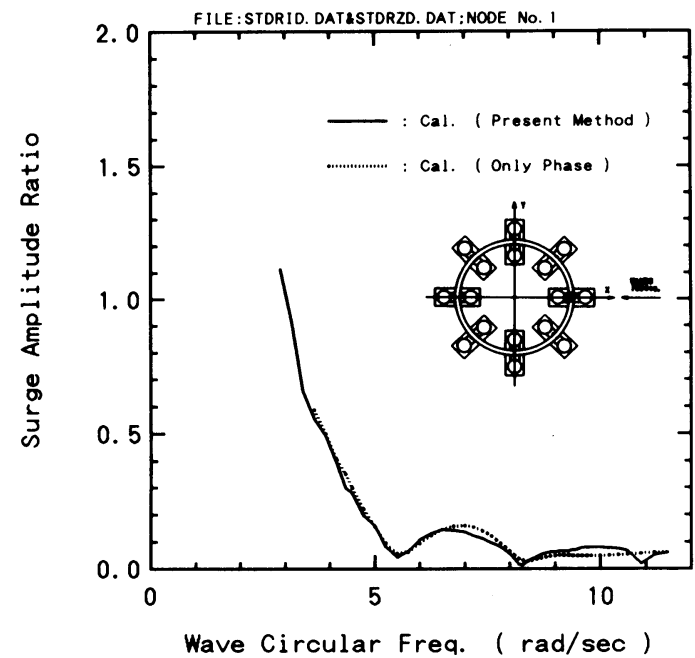

(a)

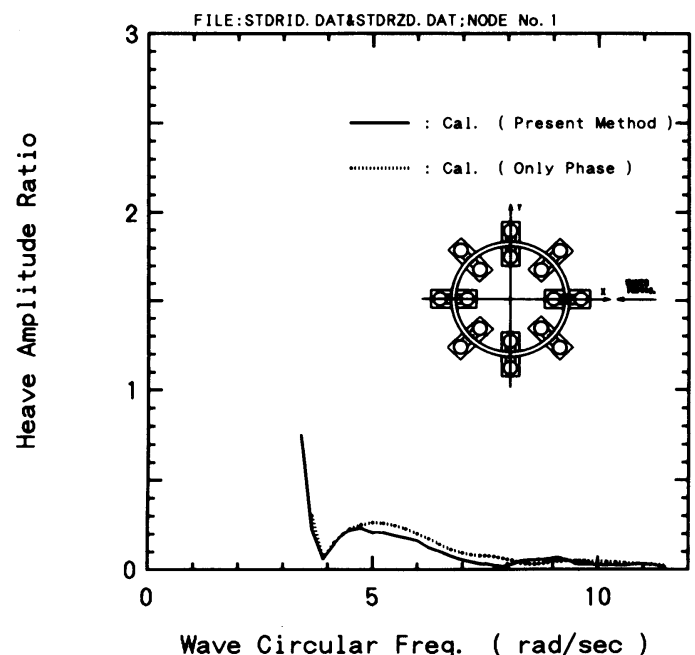

(b)

Fig. 10 Motion responses of the upper structure 


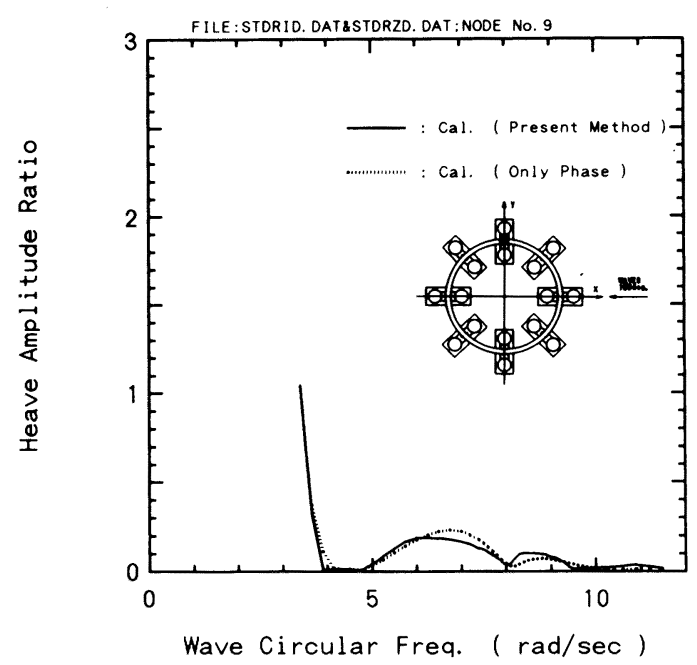

(c)

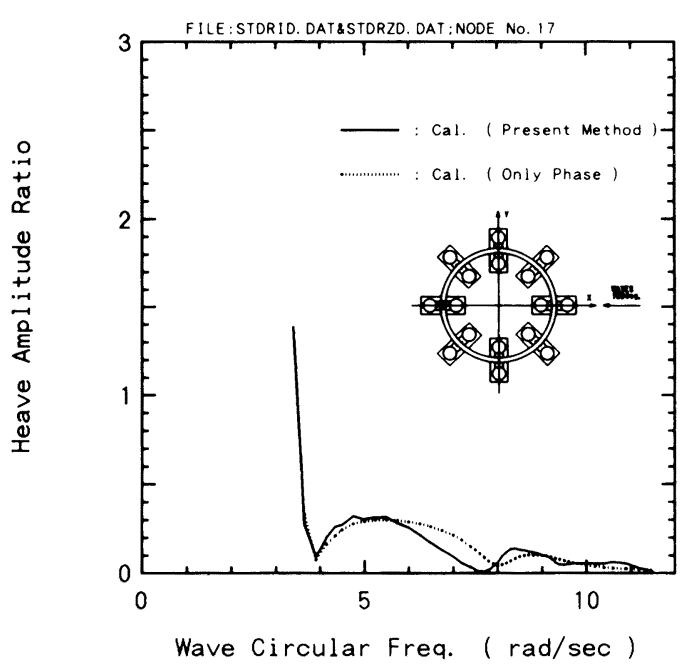

(d)

Fig. 10 Motion responses of the upper structure

ていない波上側の傾向が相当違っていたが，その他はわず かの差がみられる程度であった。Fig.10の（a ) は単位波振 幅当りの surge の運動振幅の周波数応答である。また, Fig. 10 の (b)，（c)，(d) は単位波振幅当りの heave の運動振 幅の周波数応答である。支持浮体が半潜水式であることと 上部構造が存在するため, 相互干涉の影響があまり目立つ ていないことがわかる。これは先に発表した拘束を受けな い 40 個の箱型浮体の運動応答と異なる傾向を見せている 1)。

\section{5. 結言}

三次元特異点分布法, 相互干涉理論及びマトリックス構 造応答解析法を組み合わせて, 多数の三次元任意形状支持 浮体間の流体力学的相互干渉効果と上部構造部材の剛性を 考慮して半潜水式構造の波浪荷重に対する運動一構造応答 を解析する方法を開発し，この手法による計算値と実験值 との比較検討結果, 本手法の妥当性が確かめられた。また, 本解析法は多数の浮体で支持された海洋空間利用構造体の ような上部構造の相対的な弾性変形が大きい場合に有効で あると思われる。また, 支持浮体が半潜水式であることと 上部構造が存在するため, 運動応答の相互干涉効果が余り 目立たないことは前報の 40 個の箱型浮体の運動応答と異 なる傾向を見せている。

今後は, 著者らが先に発表した中水深域空間利用構造体 ${ }^{9}$ のような上部構造と支持基礎の弾性変形を含む流力弾性問 題の構造応答解析手法に対して, 引続き研究を進めて行く 考えである。また, 計算時間 (CPU) は 1 周波数当り, 相 互干涉を考慮した計算と位相だけ考慮した計算を同時に解 く場合，約 $50 \mathrm{sec}$ である (日立 M- $680 \mathrm{H}$ 使用)。

\section{参 考 文 献}

1）具 滋三, 吉田宏一郎：多数の三次元任意形状物体 間の相互干涉, 日本造船学会論文集, 第 165 号 (1989), p. 193 202.

2) Kagemoto, H. and Yue, D. K. P.: Interactions among multiple three-dimensional bodies in water waves. An exact algebraic methed, Journal of Fluid mechenics, Vol. 166 (1986), p. 189 $\sim 209$.

3) Kagemoto, H. and Yue, D. K. P.: Wave-induced motions of multiple floating bodies, Journal of the Society of Navel Architects of Japan, Vol. 161 (1987), p. $152 \sim 158$.

4）吉田宏一郎, 石川邦照, 飯田国廣: 浮遊骨組構造の 周期応答解析, 日本造船学会論文集, 第 136 号 (1974), p. 355 363.

5）吉田宏一郎, 石川邦照: 浮遊骨組構造の周期応答解 析（続報），日本造船学会論文集，第 138 号 (1975), p. $285 \sim 294$.

6）吉田宏一郎, 石川邦照: 三次元浮遊骨組構造の周期 応答, 日本造船学会論文集, 第 143 号 (1978), p. 286 $\sim 300$.

7）吉田宏一郎, 安藤定雄, 岡 徳昭, 矢後清和：大型 半潜水式海洋構造物の波浪応答特性, 第 5 回海洋工 学シンポジウム, 日本造船学会, 1981, p. 39〜51.

8）吉田宏一郎, 尾崎雅彦, 岡 徳昭: 緊張媻留プラッ トフォームの構造応答特性, 日本造船学会論文集, 第 152 号 (1983), p. 329 335.

9）吉田宏一郎, 有馬俊朗, 岡 徳昭: 中水深域空間利 用構造体の開発一半潜水式リング状構造体の検討 一, 日本造船学会論文集, 第 165 号 (1989), p. 203 $\sim 213$. 